\title{
COMPARISON OF THE RESPONSES TO NaCl STRESS OF THREE TOMATO INTROGRESSION LINES
}

\author{
Fedia Rebah,,${ }^{1,2}$ Chayma Ouhibi, ${ }^{1}$ K. H. Alamer, ${ }^{3}$ Najoua Msilini, ${ }^{1}$ \\ Mouniba Ben NasRi, ${ }^{1}$ Rebecca Stevens ${ }^{2}$ and Houneida Attia ${ }^{1,3}$ \\ ${ }^{1}$ Unité de Physiologie et Biochimie de la Réponse des Plantes aux Contraintes Abiotiques, \\ Département de Biologie, Faculté des Sciences de Tunis, Université Tunis El Manar, \\ 1068 Tunis, Tunisie \\ ${ }^{2}$ INRA, UR1052, Génétique et Amélioration des Fruits et Légumes, F-84143 Montfavet, France \\ ${ }^{3}$ Biology Department, Faculty of Science, Taif University, Kingdom of Saudi Arabia
}

(Received: April 19, 2018; accepted: July 5, 2018)

\begin{abstract}
We aimed to examine the response of three tomato introgression lines (IL925.3, IL925.5 and IL925.6) to $\mathrm{NaCl}$ stress. These lines originated from a cross between M82 (Solanum lycopersicum) and the wild salttolerant tomato Solanum pennellii, each line containing a different fragment of the S.pennellii genome. Salt-sensitive phenotypes related to plant growth and physiology, and the response of antioxidants, pigments and antioxidant enzymes were measured. In general, salt stress decreased the fresh weight of leaves, leaf area and leaf number and an increase of $\mathrm{Na}^{+}$accumulation in aerial parts was observed, which caused a reduction in the absorption of $\mathrm{K}^{+}$and $\mathrm{Ca}^{2+}$. Salt stress also induced a decrease in chlorophyll, carotenoids and lipid peroxidation (MDA) and an increase in anthocyanins and reduced ascorbate, although some differences were seen between the lines, for example for carotenoid levels. Guaiacol peroxidase, catalase and glutathione reductase activity enhanced in aerial parts of the lines, but again some differences were seen between the three lines. It is concluded that IL925.5 might be the most sensitive line to salt stress as its dry weight loss was the greatest in response to salt and this line showed the highest $\mathrm{Na}^{+}$ion accumulation in leaves.
\end{abstract}

Keywords: Antioxidant enzymes - ascorbate - introgression lines - salinity - tomatoes - variability

\section{INTRODUCTION}

Tomato has an important place in the human diet since it is consumed throughout the year and worldwide. It is therefore important for plant breeders. According to Sharifova et al. [60] the cultivated tomato (Solanum lycopersicum L.) is economically one of the most important plants grown in the Solanaceae family. The species of cultivated tomato has been widely studied in terms of genetics, genomics and reproduction [24]. A large phenotypic variability of tomato exists, for example fruits vary widely in shape and size $[10,29]$. The diversity of wild tomato has been enriched by a wide range of ecological conditions that the species grows under. This wide variation was also seen at morphological, physiological, sexual and molecular levels [49]. Currently, more than 83,000 tomato accessions are stored in seed banks around

*Corresponding author; e-mail address: chayma.ouhibi@gmail.com 
the world, which makes tomato the highest ranked vegetable species collected (FAO, 2010). Also included among selection criteria, was the improved content of beneficial components for health such as antioxidants (lycopene, vitamin C). This can be achieved through specific mutations such as $\mathrm{hp} \mathrm{[37]} \mathrm{or} \mathrm{with} \mathrm{the} \mathrm{introgression} \mathrm{of} \mathrm{genes}$ from wild relatives. In order to obtain lines adapted to unfavorable conditions with better quality and better resistance to pathogens, efforts have been made to select new varieties of tomato and a range of varieties has been created using conventional selection methods. In this context the work of Eshed and Zamir [20] was of interest as they created a population of introgression lines using M82 (Solanum lycopersicum) crossed with Solanum pennellii. The wild species (S. pennellii) was a source of genetic variability for many characters, and was used to introgress regions into the genome of the cultivated species, thereby obtaining a population of introgression lines (ILs) containing a small fragment of the wild species in the genetic background of M82 [22]. The objectives included improving plant resistance to biotic and abiotic stresses.

Salinity is a major environmental stress and the major limitation on agricultural production [67]. According to Bolarin et al. [11], tomato is moderately sensitive to salt stress at all stages of development (germination, yield, vegetative growth and reproduction). Tolerance of tomato to salinity is a multigenic trait [23]. However Solanum pennellii is more tolerant to salt stress and maintains dry weight and yield $[57,64,65]$. Plants respond to salt stress by physiological, biochemical and genetic responses [69]. Saeed et al. [55] studied the variability in the response to salt in nine tomato accessions: root elongation data showed six accessions (LA2661, CLN2498A, CLN1621L, BL1176, 6233 and 17870) that were considered tolerant to salinity and three others (17902, LO2875 and LO4360) as being non-tolerant to salinity. The study of the ionic status showed that six tomato accessions considered tolerant had $\mathrm{Na}^{+}$exclusion capacity. In response to abiotic stress the plant produces enzymatic and non-enzymatic antioxidant molecules in order to repair oxidative damage and remove damaged molecules. Following exposure to salt stress $S$. pennellii has better foliar and root enzymatic antioxidant activity compared to L. esculentum [39, 40]. Frary et al. [26], showed that, under salt stress, the wild species $S$. pennellii revealed greater induction of all antioxidants except peroxidase. The S. pennellii introgression lines (IL) showed diverse responses to salinity and proved very useful for the identification of QTL. These results show that the antioxidant profiles, salt-induced antioxidant responses and growth responses of $S$. lycopersicum, S. pennellii and the ILs were complex. Although it was generally observed that salt stress resulted in higher levels of antioxidant compounds and enzymes in the wild species, a direct correlation between antioxidant levels and salinity tolerance was more difficult to prove [26].

The aim of this work was to make a comparative study of the variability of three tomato introgression lines that were genetically different, each carrying a different fragment of the chromosome 9 of S. pennellii in the genetic background of S. lycopersicum M82 [27]. This region has previously been associated with improved response to stress and increased antioxidant content $[61,63,26]$. 


\section{MATERIAL AND METHODS}

\section{Plant material and culture conditions}

Three tomato introgression lines (IL925.3, IL925.5 and IL925.6) [21] were first sterilized in $10 \%(\mathrm{v} / \mathrm{v}) \mathrm{H}_{2} \mathrm{O}_{2}$ for 20 min, then thoroughly washed with distilled water and germinated on moistened filter paper at $25{ }^{\circ} \mathrm{C}$ in the dark for 8 days. Uniform seedlings were transferred to pots containing $1 \mathrm{~L}$ of aerated, four-fold diluted nutritive solution of Hoagland and Arnon [31], with one plant per pot. The solution contained $0.25 \mathrm{mM} \mathrm{MgSO}_{4}, 0.125 \mathrm{mM} \mathrm{KH}_{2} \mathrm{PO}_{4}, 0.625 \mathrm{mM} \mathrm{Ca}\left(\mathrm{NO}_{3}\right)_{2}, 0.625 \mathrm{mM} \mathrm{KNO}_{3}, 0.5$ $\mu \mathrm{M} \mathrm{MnSO}_{4}, 0.25 \mu \mathrm{M} \mathrm{ZnSO}_{4}, 5 \mu \mathrm{M} \mathrm{H}_{3} \mathrm{BO}_{3}, 0.025 \mu \mathrm{M}\left(\mathrm{NH}_{4}\right) \mathrm{Mo}_{7} \mathrm{O}_{24}$, and $1.5 \mu \mathrm{M}$ FeEDTA. It was renewed weekly. The photoperiod was $16 \mathrm{~h}$ with $150 \mathrm{~mol} \mathrm{~m}^{-2} \mathrm{~s}^{-1}$ PAR at the plant level. The day/night temperature and relative humidity regimes were $22 / 18^{\circ} \mathrm{C}$ and $60 / 80 \%$, respectively.

\section{Plant morphology, growth and ion accumulation}

At 32 days of age, the tomato plants of the three lines were divided into 2 batches: the first one was the control and for the second one $100 \mathrm{mM} \mathrm{NaCl}$ was added to the nutrient solution. Eight days later, five plants per treatment were harvested (final harvest). Fresh weights (FW) were determined immediately. The morphological parameters were also determined (number of leaves, stem length), leaf areas were measured on each plant using a scanner and Optimas ${ }^{\circledR}$ software. The samples were then oven-dried for $48 \mathrm{~h}$ at $70{ }^{\circ} \mathrm{C}$ to determine the dry weight. Specific leaf area (SLA), degree of succulence and degree of sclerophylly were also determined and were calculated as follows:

SLA $=$ leaf area/dry mass [9].

Degree of succulence $=$ water mass/leaf area [15].

Degree of sclerophylly $=$ dry mass/leaf area. [68]

Ions $\mathrm{Na}^{+}, \mathrm{K}^{+}$and $\mathrm{Ca}^{2+}$ were extracted from $25 \mathrm{mg}$ samples of dried tissues with $0.5 \% \mathrm{HNO}_{3}$ for $48 \mathrm{~h}$, filtered, and assayed by flame photometry (Eppendorf) using butane-air flame for $\mathrm{K}^{+}$and $\mathrm{Na}^{+}$, and acetylene-air flame for $\mathrm{Ca}^{2+}$.

\section{Chlorophyll and carotenoid contents}

For each treatment, five plants were used and individually treated. Young fresh leaves (fifth leaf stage) of each plant were separately incubated in the dark for $72 \mathrm{~h}$ at $4{ }^{\circ} \mathrm{C}$ in acetone $80 \%(\mathrm{v} / \mathrm{v})$. Absorbance of each of the acetone extracts was measured at 470,646 , and $663 \mathrm{~nm}$ with a DU 640 Beckman spectrophotometer. Concentrations of chlorophyll a, chlorophyll b, total chlorophylls, and total carotenoids were calculated using the equations proposed by Lichtenthaler [36]. 


\section{Leaf anthocyanin concentration}

Anthocyanin concentrations in leaves were determined according to the method of Murray and Hackett [43]. Leaf discs were excised and placed in $\mathrm{HCl}, \mathrm{H}_{2} \mathrm{O}, \mathrm{MeOH}$ $(1 \mathrm{v}, 3 \mathrm{v}, 16 \mathrm{v})$ for 72 hours at $4{ }^{\circ} \mathrm{C}$. Anthocyanin concentrations were measured at 530 and $653 \mathrm{~nm}$.

\section{Lipid peroxidation}

Lipid peroxidation was determined using the thiobarbituric acid (TBA) reaction to measure the tissue content in MDA [70]. The extraction of MDA was performed by grinding $0.3 \mathrm{~g}$ of tissue with $3 \mathrm{~mL}$ of cold $0.1 \%$ trichloroacetic acid (TCA). The homogenate was then centrifuged at $10000 \mathrm{~g}$ for $15 \mathrm{~min}$ at $4{ }^{\circ} \mathrm{C}$. The MDA content was measured according to the method of Heath and Packer [30]. A 2 mL aliquot of the supernatant was added to $2 \mathrm{~mL}$ of $0.5 \%$ 2-thiobarbituric acid (TBA) in $20 \%$ TCA. The mixture was heated at $95^{\circ} \mathrm{C}$ for $30 \mathrm{~min}$, cooled in an ice bath and centrifuged at $10,000 \mathrm{~g}$ for $15 \mathrm{~min}$. Absorbance of the supernatant at $532 \mathrm{~nm}$ was corrected for nonspecific absorbance by subtracting the absorbance at $600 \mathrm{~nm}$, and the MDA concentration was estimated using $155 / \mathrm{mM} / \mathrm{cm}$ as the extinction coefficient. Five different plants were used as replicates.

\section{Protein extraction and enzymatic assays}

Fresh powder $(0.5 \mathrm{~g})$ was extracted by adding $50 \mathrm{mM}$ potassium phosphate buffer ( $\mathrm{pH} 7), 5 \%$ Polyvinylpyrrolidone, 5\% glycerol, $1 \mathrm{mM}$ dithiothreitol and $1 \mathrm{mM}$ EDTA. The homogenate was centrifuged at $13,000 \mathrm{~g}$ at $4{ }^{\circ} \mathrm{C}$ for $20 \mathrm{~min}$. The soluble protein content was determined according to the method of Bradford [12], using the Bio-Rad protein assay reagent (Bio-Rad, Foster City, CA) and bovine serum albumin as a standard.

The guaiacol peroxidase (GPX), catalase (CAT) and glutathione reductase GR assays were measured using the same extraction procedure. For $0.5 \mathrm{~g}$ of aerial parts, $1 \mathrm{~mL}$ of phosphate buffer $(50 \mathrm{mM}, \mathrm{pH} 7.5)$, which contained $5 \%$ polyvinylpolypyrrolidone (PVPP), 5\% glycerol, $1 \mathrm{mM}$ DTT and $1 \mathrm{mM}$ EDTA was used as the extraction buffer. The solution was then centrifuged at $13,000 \mathrm{~g}$ for $20 \mathrm{~min}$ at $4{ }^{\circ} \mathrm{C}$.

For the measurement of guaiacol peroxidase (GPX) activity, the reaction mixture contained $50 \mathrm{mM}$ phosphate buffer ( $\mathrm{pH}$ 7), $9 \mathrm{mM}$ guaiacol, $12 \mathrm{mM} \mathrm{H}_{2} \mathrm{O}_{2}$, and $60 \mu \mathrm{L}$ of supernatant. GPX activity was determined by the increase in absorbance at $470 \mathrm{~nm}$ due to guaiacol oxidation (extinction coefficient $=26.6 \mathrm{mM}^{-1} \mathrm{~cm}^{-1}$ ) [44].

The CAT activity was estimated according to the method of Chance and Maehly [13]. The reaction mixture consisted of $40 \mu \mathrm{L}$ of enzyme extract, $25 \mathrm{mM}$ phosphate buffer ( $\mathrm{pH} 7$ ) and $30 \mathrm{mM} \mathrm{H}_{2} \mathrm{O}_{2}$. The depletion of $\mathrm{H}_{2} \mathrm{O}_{2}$ was determined by measuring the change in the absorbance at $240 \mathrm{~nm}$ using a UV-visible spectrophotometer. One 
unit of CAT was defined as the amount of enzyme needed to reduce $1 \mathrm{~mol}_{2} \mathrm{O}_{2}$ in $1 \mathrm{~min}$. The specific activity was expressed as units per gram of fresh weight.

The glutathione reductase (GR) activity was determined by following the oxidation of NADPH at $340 \mathrm{~nm}$ (extinction coefficient $6.2 \mathrm{mM} \mathrm{cm}^{-1}$ ) as described by Rao [52] One $\mathrm{mL}$ assay mixture contained $100 \mathrm{mM}$ potassium phosphate buffer ( $\mathrm{pH}$ 7.8), $2 \mathrm{mM}$ EDTA, $0.2 \mathrm{mM}$ NADPH, $0.5 \mathrm{mM} \mathrm{GSSG}$, and the leaf extract. The assays were initiated by the addition of NADPH at $25^{\circ} \mathrm{C}$. Corrections were made for any GSSG oxidation in the absence of NADPH.

\section{Ascorbic acid}

The ascorbic acid contents were measured according to the method described by Stevens et al. [62]. One g $(1 \mathrm{~g})$ of powder was homogenized with $600 \mathrm{~mL}$ of ice-cold $6 \%$ trichloroacetic acid (TCA). Samples were centrifuged for $15 \mathrm{~min}$ at 25,000 $\mathrm{g}$ at $4{ }^{\circ} \mathrm{C}$. Twenty $\mu \mathrm{L}(20 \mu \mathrm{L})$ of the supernatant was used in each assay. Two assays were carried out on each sample, one to measure the total ascorbate, including the addition of $5 \mathrm{mM}$ dithiothreitol (DTT), and one to quantify the reduced ascorbate form and this by using $0.4 \mathrm{mM}$ phosphate buffer ( $\mathrm{pH}$ 7.4) (omission of DTT from the assay). The samples were incubated at $37^{\circ} \mathrm{C}$ for $20 \mathrm{~min}$. Thereafter $\mathrm{N}$-ethyl malemide was added for measuring total ascorbate, or $0.4 \mathrm{mM}$ phosphate buffer $(\mathrm{pH} 7.4)$ to measure reduced ascorbate. Once added and mixed we followed the reaction of the color reagent which contains $85 \%$ orthophosphoric acid $\left(\mathrm{H}_{3} \mathrm{PO}_{4}\right), 4.6 \%$ TCA, $0.6 \%$ Ferric chloride $\left(\mathrm{FeCl}_{3}\right), 2.4 \%$ dipyridyl in $70 \%$ ethanol. After incubation at $37{ }^{\circ} \mathrm{C}$ for 40 min, the absorbance was read at $550 \mathrm{~nm}$.

\section{Statistical analysis}

All data were initially analyzed to check if they followed a normal distribution using the Tukey and Fisher test, then two-way ANOVA were carried out using XIStat. Means ( \pm standard error) were separated and ranked using the Fisher post hoc test $(P=0.05)$.

\section{RESULTS}

For this study we chose to work on the aerial part of the plant. Salt stress negatively affected all of the growth parameters measured in aerial parts in the three introgression lines of tomato, but in a different way from one line to another. Analysis of variability revealed significant differences in dry weights of the different introgression lines of tomato. Dry weight was strongly affected by salinity treatments (Fig. 1), in whole plants it was significantly lower under salinity. Indeed, the reduction was $77 \%, 36 \%$ and $26 \%$ in IL925.3, IL925.5 and IL925.6, respectively. Under control 
conditions, the difference between the three lines for the number of leaves was only significant for IL925.5 which has a lower number of leaves than the other two lines. Under saline conditions, IL925.3 presents a number of leaves similar to IL925.5 under control conditions. Plant leaf number was reduced by $20 \%, 21 \%$ and $35 \%$ respectively in IL925.3, IL925.5 and IL925.6 under salinity (Table 1). For stem length, Table 1 shows that IL925.5 has the shortest length relative to the other lines under control conditions. This parameter was affected by salinity treatments; the reduction was respectively by $30 \%, 18 \%$ and $20 \%$ in IL925.3, IL925.5 and IL925.6, but the difference between the three lines was not significant (Table 1). In the absence of $\mathrm{NaCl}$ in the medium, IL925.3 has the highest leaf area followed by IL925.6; IL925.5 presents the lowest leaf area compared to the other two lines. The salt treatment decreased the total leaf surface area by $64 \%, 22 \%$ and $40 \%$, respectively, in IL925.3, IL925.5 and IL925.6. However, the leaf expansion of IL925.5 was not greatly affected by the presence of $\mathrm{NaCl}$ as compared to the other lines (Table 1). Under control conditions leaf thickness in IL925.5 was significantly higher than in IL925.3 and IL925.6, and following treatment with $100 \mathrm{mM} \mathrm{NaCl}$, increased leaf thickness was noted in also three lines but it was statistically more pronounced in IL925. The degree of leaf sclerophylly in control conditions was highest in IL925.3. Salt treatment results in regression of the leaf sclerophylly except for IL925.6 where salinity causes a significant increase compared to the control. The degree of succulence was higher in control conditions for IL925.5, followed by IL925.6 and finally IL925.3, while under salt conditions a significant increase was observed in both lines IL925.3 and IL925.6 except for IL925.5 where there was no significant difference between the two conditions. In plants grown in saline condition, the lines IL925.5 and IL925.6 presented the lowest foliar concentrations of $\mathrm{Na}^{+}$, while IL925.3 registered

Table 1

Morphology parameters: stem length, leaf number, number of stem shoots, total leaf area and individual leaf area of tomato. Thirty two-days-old plants grown in nutritive solution, at this age $100 \mathrm{mM} \mathrm{NaCl}$ was added to the nutrient solution (S). Control plants $(C)$ had no salt added. Plants were harvested after 8 days. Mean of five plants and confidence interval for $P=0.05$. Mean values with the same letter in each panel were not significantly different at $P=0.05$ (ANOVA and mean comparison with fisher post hoc test)

\begin{tabular}{|l|c|c|c|c|c|c|}
\hline \multirow{2}{*}{ Parameters } & \multicolumn{2}{c|}{ IL9.2.5.3 } & \multicolumn{2}{c|}{ IL9.2.5.5 } & \multicolumn{2}{c|}{ IL9.2.5.6 } \\
\cline { 2 - 7 } & $\mathrm{C}$ & $\mathrm{S}$ & $\mathrm{C}$ & $\mathrm{S}$ & $\mathrm{C}$ & $\mathrm{S}$ \\
\hline Stem length, cm & $27 \pm 1^{\mathrm{a}}$ & $19 \pm 0^{\mathrm{cd}}$ & $22 \pm 1^{\mathrm{b}}$ & $18 \pm 1^{\mathrm{d}}$ & $25 \pm 1^{\mathrm{a}}$ & $20 \pm 1^{\mathrm{bc}}$ \\
\hline Leaf number & $30 \pm 1^{\mathrm{a}}$ & $24 \pm 1^{\mathrm{b}}$ & $24 \pm 1^{\mathrm{b}}$ & $19 \pm 1^{\mathrm{c}}$ & $29 \pm 2^{\mathrm{a}}$ & $19 \pm 1^{\mathrm{c}}$ \\
\hline Number of stem shoots & $7 \pm 0^{\mathrm{ab}}$ & $6 \pm 0^{\mathrm{bc}}$ & $6 \pm 1^{\mathrm{bc}}$ & $5 \pm 1^{\mathrm{c}}$ & $8 \pm 1^{\mathrm{a}}$ & $5 \pm 1^{\mathrm{c}}$ \\
\hline Total leaf area, cm plant $^{-1}$ & $22 \pm 3^{\mathrm{a}}$ & $8 \pm 0^{\mathrm{cd}}$ & $9 \pm 1^{\mathrm{c}}$ & $7 \pm 1^{\mathrm{d}}$ & $15 \pm 2^{\mathrm{b}}$ & $9 \pm 1^{\mathrm{cd}}$ \\
\hline $\begin{array}{l}\text { Individual leaf area, } \mathrm{cm}^{2} \\
\text { leave }\end{array}$ & $3.1 \pm 0.4^{\mathrm{a}}$ & $1.4 \pm 0.1^{\mathrm{d}}$ & $1.5 \pm 0.1^{\mathrm{cd}}$ & $1.3 \pm 0^{\mathrm{d}}$ & $1.9 \pm 0.1^{\mathrm{b}}$ & $1.7 \pm 0.2^{\mathrm{bc}}$ \\
\hline Leaf thickness, cm $^{*} \mathrm{~cm}$ & $0.2 \pm 0^{\mathrm{e}}$ & $0.9 \pm 0.1^{\mathrm{bc}}$ & $1.1 \pm 0.1^{\mathrm{b}}$ & $1.8 \pm 0.1^{\mathrm{a}}$ & $0.4 \pm 0.1^{\mathrm{d}}$ & $0.7 \pm 0.1^{\mathrm{c}}$ \\
\hline Leaf sclerophylly, $\mathrm{mg} \mathrm{cm}^{-2}$ & $155 \pm 6^{\mathrm{a}}$ & $97 \pm 6^{\mathrm{c}}$ & $65 \pm 5^{\mathrm{d}}$ & $54 \pm 5^{\mathrm{e}}$ & $104 \pm 5^{\mathrm{c}}$ & $126 \pm 4^{\mathrm{b}}$ \\
\hline Leaf succulence, $\mathrm{mg} \mathrm{cm}^{-2}$ & $511 \pm 56^{\mathrm{c}}$ & $744 \pm 9^{\mathrm{ab}}$ & $649 \pm 51^{\mathrm{b}}$ & $661 \pm 89^{\mathrm{b}}$ & $630 \pm 40^{\mathrm{bc}}$ & $836 \pm 63^{\mathrm{a}}$ \\
\hline
\end{tabular}


the highest concentrations $\left(33 \mathrm{mmol} \cdot \mathrm{g}^{-1} \mathrm{MS}\right) . \mathrm{K}^{+}$concentrations in leaves were significantly different in IL925.6 which presented the lowest concentration of $\mathrm{K}^{+}$in control conditions. Under salt treatment, $\mathrm{K}^{+}$was reduced in the three lines but the most dramatic regression has been observed in IL925.3 and IL925.5. Indeed, the reductions were $54 \%$ and $50 \%$, respectively in IL925.3 and IL925.5. However, the accumulation of $\mathrm{K}^{+}$in IL925.6 decreased by $17 \%$. Under salinity, there was a decrease in the accumulation of $\mathrm{Ca}^{2+}$ : by $49 \%, 43 \%$, and $29 \%$, respectively in IL925.3, IL925.5 and IL925.6 (Fig. 1).

Under control conditions total chlorophyll content was similar in IL925.3 and IL925.5 while IL925.6 has a lower content. Total chlorophylls were affected by salt
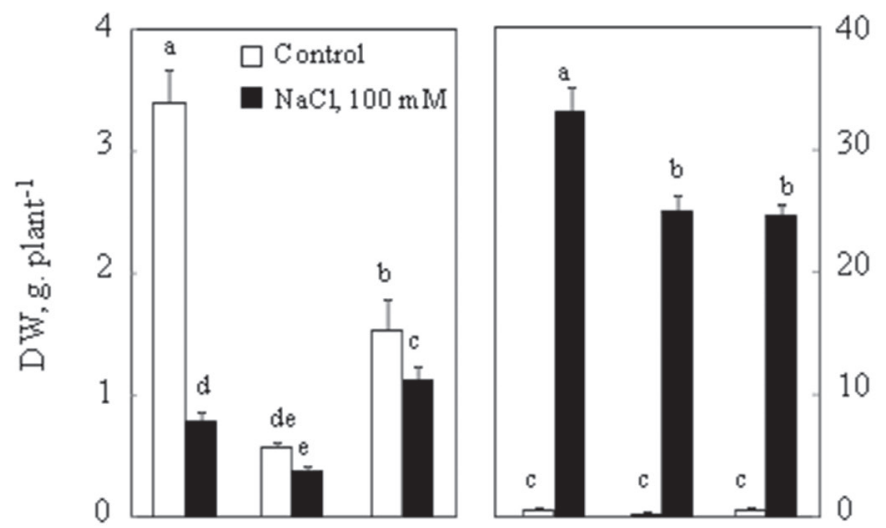

40
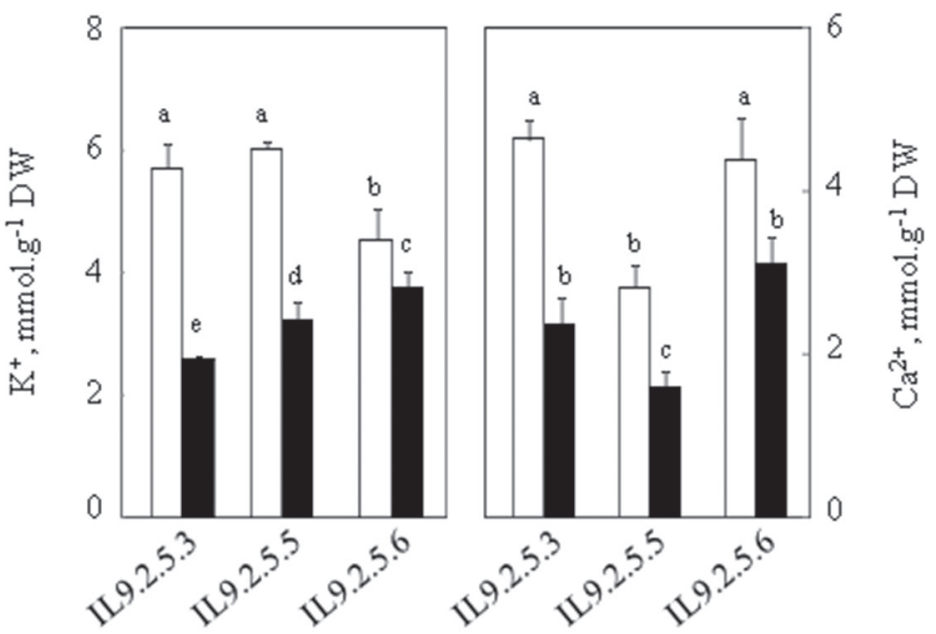

Fig. 1. Dry weights (DW), $\mathrm{Na}^{+}, \mathrm{K}^{+}$and $\mathrm{Ca}^{2+}$ contents of aerial parts of plants. Thirty two-day-old plants grown in nutritive solution, at this age $100 \mathrm{mM} \mathrm{NaCl}$ was added to the nutrient solution (S). Control plants $(C)$ had no salt added. Plants were harvested after 8 days. Mean of five plants per treatment and confidence interval for $P=0.05$. Mean values with the same letter in each panel were not significantly different at $P=0.05$ (ANOVA and mean comparison with Tukey and Fisher test) 
Table 2

Contents of chlorophylls a, b, total chlorophylls, carotenoids and anthocyanins in the leaves of tomatoes were measured. Thirty two-day-old plants grown in nutritive solution, at this age $100 \mathrm{mM} \mathrm{NaCl} \mathrm{was}$ added to the nutrient solution (S). Control plants (C) had no salt added. Plants were harvested after 8 days. Mean of five plants and confidence interval for $P=0.05$. Mean values with the same letter in each panel were not significantly different at $P=0.05$ (ANOVA and mean comparison with fisher post hoc test)

\begin{tabular}{|l|c|c|c|c|c|c|}
\hline \multirow{2}{*}{ Pigment, $\mathrm{mg} \cdot \mathrm{g}^{-1} \mathrm{FW}$} & \multicolumn{2}{|c|}{ IL9.2.5.3 } & \multicolumn{2}{c|}{ IL9.2.5.5 } & \multicolumn{2}{c|}{ IL9.2.5.6 } \\
\cline { 2 - 7 } & $\mathrm{C}$ & $\mathrm{S}$ & $\mathrm{C}$ & $\mathrm{S}$ & $\mathrm{C}$ & $\mathrm{S}$ \\
\hline Chl a & $2.1 \pm 0.2^{\mathrm{b}}$ & $1.8 \pm 0.2^{\mathrm{c}}$ & $3.0 \pm 0.2^{\mathrm{a}}$ & $0.5^{\mathrm{d}}$ & $2.2^{\mathrm{d}} \pm 0.3^{\mathrm{b}}$ & $0.4^{\mathrm{a}} \pm 0.1^{\mathrm{d}}$ \\
\hline Chl b & $2.0 \pm 0.1^{\mathrm{a}}$ & $0.8 \pm 0.1^{\mathrm{c}}$ & $1.1 \pm 0.1^{\mathrm{b}}$ & $0.2^{\mathrm{d}}$ & $1.2 \pm 0.2^{\mathrm{b}}$ & $0.1^{\mathrm{d}}$ \\
\hline Chl tot & $4.1 \pm 0.2^{\mathrm{a}}$ & $2.6 \pm 0.2^{\mathrm{c}}$ & $4.1 \pm 0.2^{\mathrm{a}}$ & $0.7 \pm 0.2^{\mathrm{d}}$ & $3.3 \pm 0.3^{\mathrm{b}}$ & $0.5^{\mathrm{d}} \pm 0.1^{\mathrm{d}}$ \\
\hline Car. & $0.1^{\mathrm{d}}$ & $0.3^{\mathrm{c}}$ & $0.6^{\mathrm{a}}$ & $0.1^{\mathrm{d}}$ & $0.5^{\mathrm{b}}$ & $0.1^{\mathrm{d}}$ \\
\hline Anth & $0.011^{\mathrm{bc}}$ & $0.013^{\mathrm{ab}}$ & $0.010^{\mathrm{c}}$ & $0.006^{\mathrm{d}}$ & $0.005^{\mathrm{d}}$ & $0.014^{\mathrm{a}}$ \\
\hline
\end{tabular}

in the three introgression lines (Table 2). The total chlorophyll content of leaves was reduced in saline conditions. The reduction was more pronounced in IL925.5 and IL925.6 compared to IL925.3. Indeed the reduction was by $37 \%, 83 \%$ and $85 \%$ in IL925.3, IL925.5 and IL925.6, respectively. Concerning carotenoid content, the IL925.5 line had the highest values and IL925.3 line the lowest under control conditions. However, in the presence of $\mathrm{NaCl}$ treatment, IL925.3 had the highest carotenoid content. Under salinity, the carotenoid content in the three lines was affected. Indeed, we noted an increase in this pigment by $46 \%$ in IL925.3, in contrast to what was noted in IL925.6 and IL925.5. In fact, under salinity, we recorded a decrease in the content of carotenoids by $85 \%$ in IL925.5 and IL925.6 (Table 2). IL925.3 and IL925.5 lines have a similar level of anthocyanins under control conditions while IL925.6 was the line that presents a significant difference. Under salinity conditions, the anthocyanin concentration was affected. Indeed, we have noted an increase in IL925.3 and IL925.6 (16 and 62\%), while this content decreased in IL925.5 (40\%) (Table 2).

The malondialdehyde (MDA), which is a degradation product of lipid peroxidation, has shown a decline in the three introgression lines in the presence of $100 \mathrm{mM}$ $\mathrm{NaCl}$. Indeed, we noted a significant reduction in MDA by $46 \%, 56 \%$ and $26 \%$, respectively, in IL925.3, IL925.5 and IL925.6 (Fig. 2).

Under control conditions the amount of soluble proteins was almost similar and significantly different to IL925.6. In the presence of $100 \mathrm{mM} \mathrm{NaCl}$, a decreased amount of proteins was observed in the three subILs, this decrease was of the order of $35 \%$ in IL925.3 and IL925.5, while it was around 29\% only in IL925.6 (Fig. 3). The enzyme systems studied in this work were, guaiacol peroxidase (GPX), catalase (CAT) and an enzyme belonging to ascorbate-glutathione cycle, glutathione reductase (GR). IL925.5 presented low GPX activity under control conditions, while IL925.3 exhibits the highest activity under both conditions (Fig. 3). Under control conditions, IL 925.3 shows much higher GPX activity compared to IL925.5 and 


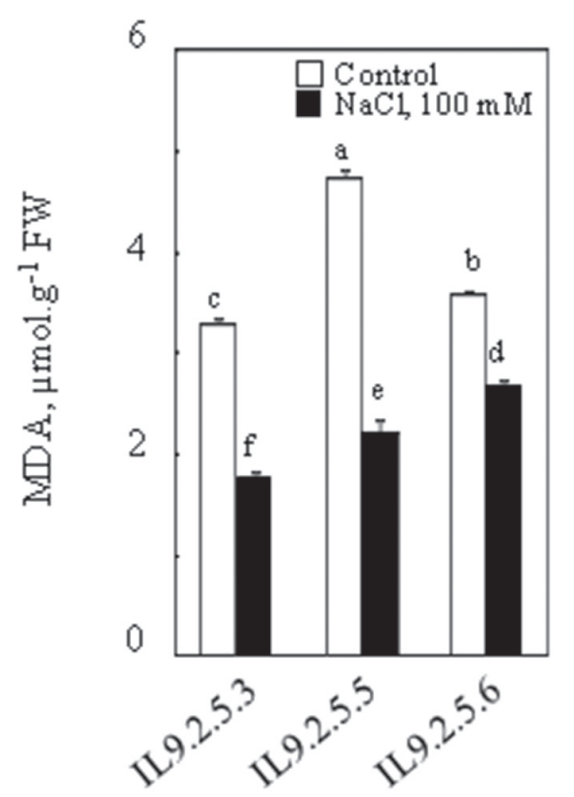

Fig. 2. Malondehyaldehyde content in aerial parts of plants. Thirty two-day-old plants grown in nutritive solution, at this age $100 \mathrm{mM} \mathrm{NaCl}$ was added to the nutrient solution (S). Control plants (C) had no salt added. Plants were harvested after 8 days. Mean of five plants per treatment and confidence interval for $P=0.05$. Mean values with the same letter in each panel were not significantly different at $P=0.05$

(ANOVA and mean comparison with Tukey and Fisher test)

IL925.6: this difference was about 4 times more, compared to IL925.5, and twice more than IL925.6. GPX was significantly increased in the presence of $100 \mathrm{mM}$ $\mathrm{NaCl}$ in the three lines in comparison with the control treatment. Similarly to GPX activity, salt stimulates the activity of CAT compared to the control in the three lines, the percentage increase of catalase activity was $52 \%, 46 \%$ and $45 \%$, respectively, for IL925.3, IL925.5 and IL925.6. Under control conditions, the CAT activity was significantly higher in IL925.6, compared to IL925.3 and IL925.5. Under saline conditions, IL925.3 and IL925.6 have the highest activity and the difference between them was not significant, while the difference was significant compared to IL925.5 (Fig. 3). Under the control conditions, IL925.6 has higher GR activity, compared to IL925.5. Salt treatments activate GR activity. Indeed, we noted an increase in their enzymatic activity by $69 \%$ and $46 \%$, respectively in IL925.5 and IL925.6 but this difference was not significant between this two lines. (Activity not determined for IL925.3) (Fig. 3).

Total ascorbate level (AsA) was only significantly different in the presence of 100 $\mathrm{mM} \mathrm{NaCl}$ in the sub ILs 925.6 where saline treatment caused an increase in the total ascorbate contrast of $38 \%$ (Fig. 4). Under control conditions, the total ascorbate concentration was almost the same for both sub ILs (IL925.5 and IL925.6). In contrast, 

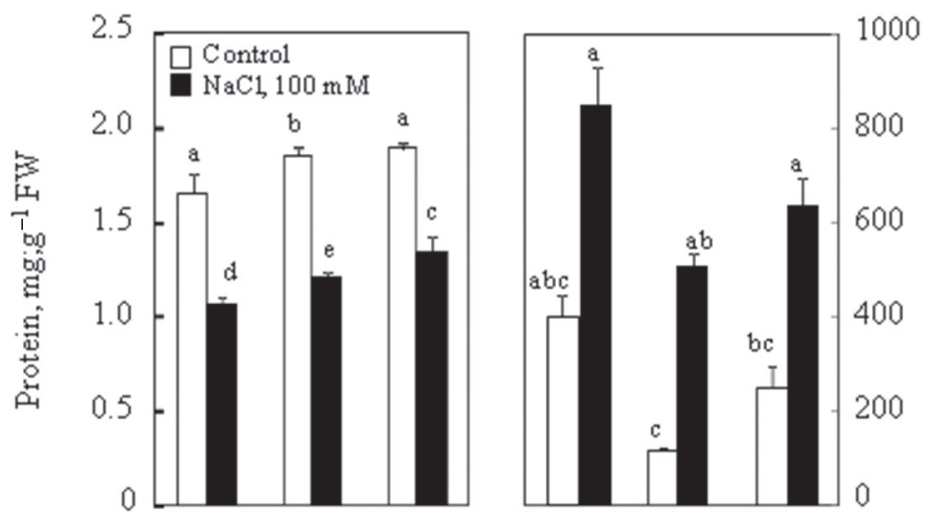

1000
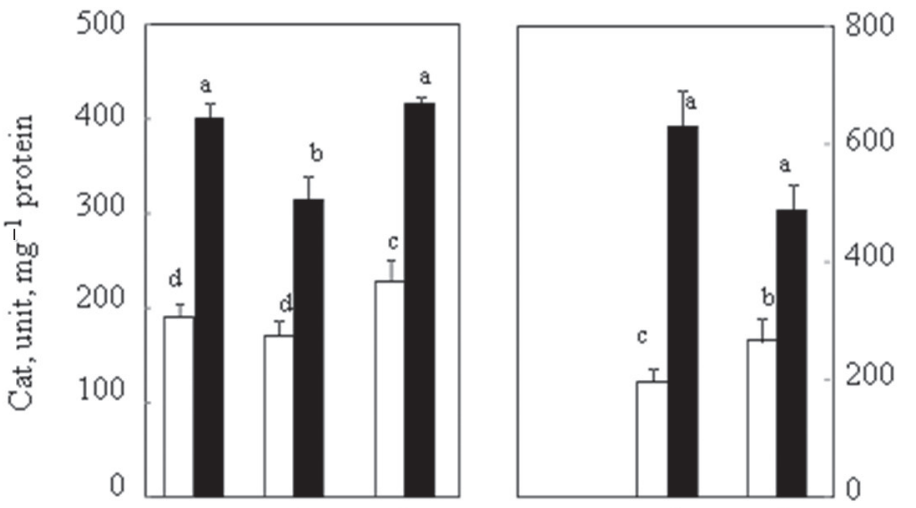

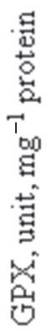<smiles>C1[As][As]=[As]1</smiles>

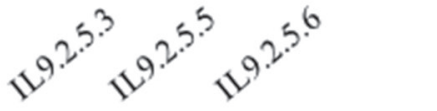

Fig. 3. Total proteins soluble content and enzymatic activity of guaiacol peroxydase (GPX), catalase (CAT) and glutathione reductase (GR) assays in aerial parts of plants. Thirty two-day-old plants grown in nutritive solution, at this age $100 \mathrm{mM} \mathrm{NaCl}$ was added to the nutrient solution (S). Control plants (C) had no salt added. Plants were harvested after 8 days. Mean of five plants per treatment and confidence interval for $P=0.05$. Mean values with the same letter in each panel were not significantly different at $P=0.05$ (ANOVA and mean comparison with Tukey and Fisher test)

IL925.3 was much less rich in ascorbate (almost half of the other two subILs). Saline treatment caused a significant increase in reduced ascorbate in these three subILs: this increase was $62 \%, 39 \%$ and $38 \%$, respectively, for IL925.3, IL925.5 and IL925.6. The variability in the changes in reduced ascorbate in the sub ILs was very clear: IL925.6 had the highest reduced ascorbate levels (Fig. 4). Dehydroascorbate (DHA) showed a significant increase (39\%) in IL925.6 following treatment of plants with $100 \mathrm{mM} \mathrm{NaCl}$ whereas in IL925.3 and IL925.5, DHA decreases with saline treatment, this decrease was respectively $73 \%$ and $65 \%$ less than the control. 

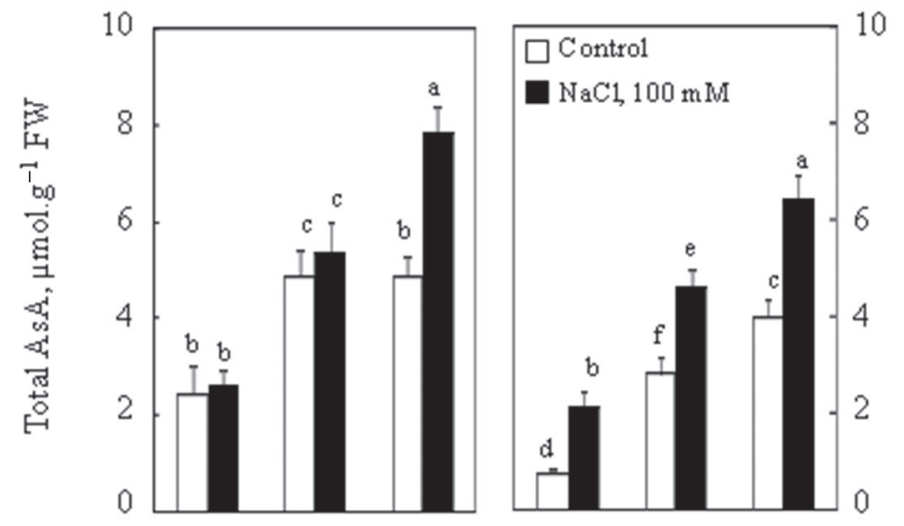

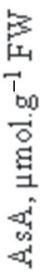
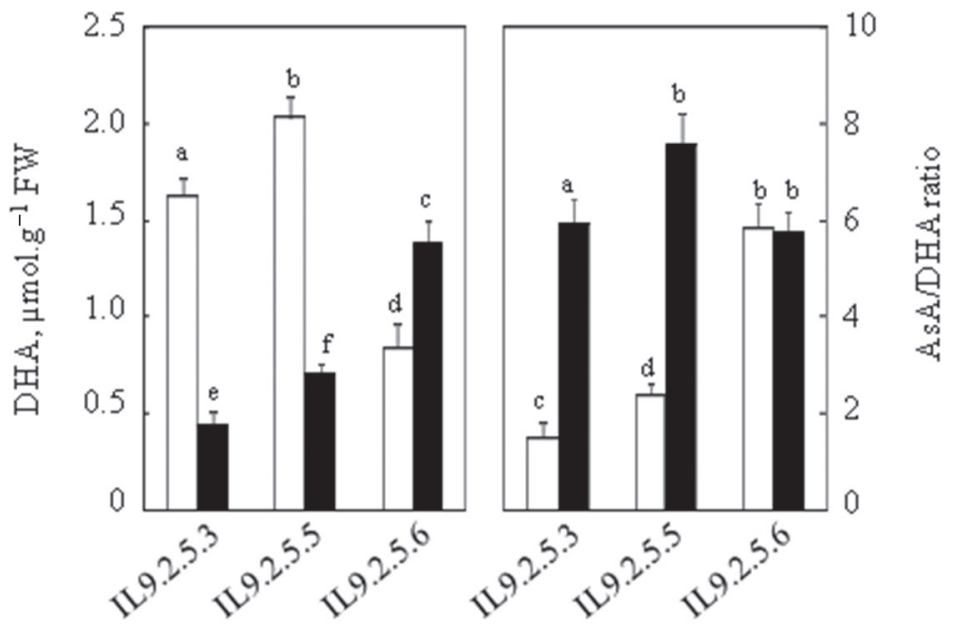

Fig. 4. Total ascorbate, ascorbate reduced and dehydroascorbate contents. Thirty two-day-old plants grown in nutritive solution, at this age $100 \mathrm{mM} \mathrm{NaCl}$ was added to the nutrient solution (S). Control plants $(\mathrm{C})$ had no salt added. Plants were harvested after 8 days. Mean of five plants per treatment and confidence interval for $P=0.05$. Mean values with the same letter in each panel were not significantly different at $P=0.05$ (ANOVA and mean comparison with Tukey and Fisher test)

\section{DISCUSSION}

Several previous studies have shown the variability of salt tolerance in tomato $[2,66]$. Plant biomass and yield can be considered as stress tolerance markers [58]. A reduced dry leaf weight of $30 \%$, and of $50 \%$ in the stems of tomato was observed by Cuartero et al. [14] following saline treatment. In our work, the lowest leaf biomass was found in IL925.5, which defines this line is the most sensitive to salt stress. Similar results were demonstrated also by Juan et al. [32] in the cultivar Royesta. 
Salt stress induces a decline in growth parameters in the lines studied: it has been proven that the answer to salinity differs depending on the concentration of salt and tomato variety used [2]. Generally, the leaf numbers of lines was affected by $\mathrm{NaCl}$ treatment. This observation was also confirmed by Munns and Termaat [41]. Indeed, they showed that salinity causes a reduction in plant growth associated with a decline in leaf area, which led to the death of the tissues, organs and whole plant at high concentrations. The leaf area reduction under salinity also affected photosynthesis [42]. Reduction of shoot number and root and stem elongation has also been demonstrated by several authors in tomato [50,71]. These reductions were also observed by Oztekin and Tuzel [45] in 33 different tomato genotypes. The excessive accumulation of $\mathrm{Na}^{+}$and $\mathrm{Cl}^{-}$in the leaves was one of the harmful effects of salinity on plant growth [5]. IL925.5 and IL925.6 presented the lowest foliar concentrations in $\mathrm{Na}^{+}$while in IL925.3 we registered the highest concentrations. Plants grown under salt stress accumulate $\mathrm{Na}^{+}$, resulting in a specific ionic imbalance and the appearance of symptoms of nutrient deficiency [32]. The increase in $\mathrm{Na}^{+}$concentration causes a decrease in $\mathrm{K}^{+}$, $\mathrm{Ca}^{2+}, \mathrm{Mg}^{2+}$ which inhibits growth [58]. The potassium content decreased in the three lines under salt stress, this has been also observed in tomato by Frary et al. [25]. Salt stress causes a potassium deficiency in plants, which can be explained by the competition between $\mathrm{Na}^{+}$and $\mathrm{K}^{+}$for the same transport system at the root surface [8,54]. Salt stress causes a decrease in leaf concentration of calcium in the three lines; this was explained by the competition between sodium and calcium through non-selective cation channels $[8,16]$. When the accumulation of $\mathrm{Na}^{+}$in the plant increases its effect becomes increasingly toxic at various physiological levels. This toxicity includes not only the nutritional disturbance $\left(\mathrm{K}^{+}\right.$and $\left.\mathrm{Ca}^{2+}\right)$, but also the development of water stress and the induction of oxidative cell damage $[3,6]$.

The decrease in chlorophyll and carotenoids under conditions of salinity was a major marker of salt tolerance; this has been demonstrated by Sairam et al. [56]. Chlorophyll content decreased in three lines at $100 \mathrm{mM} \mathrm{NaCl}$ treatment. Eryilmaz [19] also observed a decrease of $60 \%$ in chlorophyll content in tomato after 7 days of treatment with $100 \mathrm{mM} \mathrm{NaCl}$. The anthocyanin pigment content increased with saline treatment in the two lines IL925.3 and IL925.6, and this increase was significant for IL925.6. Similar result was also demonstrated by Rajamane and Gaikwad [51]. Eryilmaz [19] showed that the anthocyanin pigment content increased under treatment with $100 \mathrm{mM} \mathrm{NaCl}$, this content has been increased by $73 \%$ in cotyledons and $51 \%$ in tomato hypocotyls. Based on the results obtained, anthocyanin production seems positively correlated with the saline treatment in the aerial part of the tomato. The anthocyanin pigments increased significantly with salt stress [33].

In our study, we noted a decrease in lipid peroxidation in the three introgression lines under salinity but the line IL925.5 seems to be the most affected by $\mathrm{NaCl}$. This decrease in lipid peroxidation was seen in barley by Liang [35]. This was consistent with the results obtained by Ozturk et al. [46] in leaves of pea, and also in peanut (Arachis hypogaea L.) by Parida and Das [48]. Increased peroxidase activity accompanied by a decrease in the content of MDA under saline conditions suggests that 
peroxidases were involved in the integrity of the cell membranes [48]. The lower level of MDA under salt stress was the result of the high activities of antioxidant enzymes (SOD and peroxidase); this was observed by Shalata and Tal [59] in wild tomato species tolerant to salt, in wheat [18], pea [46] and cotton [17]. Similarly, a low level of MDA accompanied by high SOD activity and peroxidases under salt stress in cotton [38] and senna 'Cassia angustifolia Vahl' [1]. In Grevia ilicifolia, MDA levels decreased significantly after exposure to salt stress, and in parallel there was a significant increase in protease, catalase, polyphenol oxidase, SOD and lipoxygenase activities [33]. Plants have developed a powerful antioxidant system that protects against damage caused by oxidative stress. These defense barriers consist of two types: enzymatic and non-enzymatic thus protecting plant cells from oxidative damage by scavenging ROS [28]. Rodríguez-Rosales et al. [53] observed an increase in the activity of lipoxygenase and antioxidant enzymes such as SOD, catalase, ascorbate peroxidase, glutathione reductase, and glutathione- $S$-transferase in tomato under saline treatment. In our work, the activity of guaiacol peroxidase was stimulated under salinity, in the three lines of tomato. Several authors observed a simultaneous increase in this activity in leaves and roots of Vigna radiate [47], of Oryza sativa [34]. In other studies, the authors noted an increase in total peroxidase activity under saline conditions. Salt induces increases in enzymatic antioxidants, which could give the tomato lines a high capacity for scavenging ROS generated by salt stress. These results were also observed by Ozturk et al. in pea [46]. A synthesis study conducted by Parida and Das [48] showed an increase of $\mathrm{H}_{2} \mathrm{O}_{2}$ and MDA in the chloroplasts of L. esculentum treated with salt. However, $S$. pennellii shows a decrease of these indicators under the same conditions. The response of L. esculentum and S. pennellii was in positive correlation with the activities of antioxidant enzymes in the chloroplasts.

IL925.6 was richer in ascorbate than the two others subILs (IL925.3 and IL925.5), this was explained by the presence of 2 separate QTL which contribute to the increase in the total ascorbate [63]. The content of reduced ascorbate was higher in the presence of salt for the three subILs and this can be explained by the presence of a QTL which varies under the effect of the environment [61].

The salinity of the nutrient solution creates a disturbance of the nutritional status, which has caused a disruption of plant growth of the introgression lines except for the IL925.6 line which was the least sensitive to the stress, probably due to its improved compartmentalization of sodium and a better absorption of $\mathrm{K}^{+}$and $\mathrm{Ca}^{2+}$. The salt stress induced an enzymatic and non-enzymatic antioxidant response (GPX, CAT and GR and ascorbate) in three tomato lines. Indeed, in our study, we have also shown that the response of the three tomato lines to salt stress by enzymatic antioxidants was similar to the response of S. pennellii [64], this resemblance could be explained by the presence of a $S$. pennellii region in the genetic background of $L$. esculentum. 


\section{REFERENCES}

1. Agarwal, S., Pandey, V. (2004) Antioxidant enzyme responses to $\mathrm{NaCl}$ stress in Cassia angustifolia. Biol. Plant. 48, 555-560.

2. Akinci, S., Yilmaz, K., Akinci, I. E. (2004) Response of tomato (Lycopersicon esculentum Mill.) to salinity in the early growth stages for agricultural cultivation in saline environments. J. Environ. Biol. $25,351-357$

3. Aktas, H., Abak, K., Cakmak, I. (2006) Genotypic variation in the response of pepper to salinity. Sci. Hortic. 10, 260-266.

4. Alfocea, P. F., Estañ, M. T., Caro, M., Guerrier, G. (1993) Osmotic adjustment in Lycopersicon esculentum and L. Pennellii under $\mathrm{NaCl}$ and polyethylene glycol 6000 iso-osmotic stresses. Physiol. Plant 87, 493-498.

5. Ashraf, M., Harris, P. J. C. (2004) Potential biochemical indicators of salinity tolerance in plants. Plant. Sci. 116, 3-16.

6. Attia, H., Nouaili, S., Soltani, A., Lachaâl, M. (2009) Comparison of the responses to $\mathrm{NaCl}$ stress of two pea cultivars using split-root system. Sci. Hort. 123, 164-169.

7. Attia, H., Karraya, N., Rabhi, M., Lachaâl, M. (2008) Salt-imposed restrictions on the uptake of macro elements by roots of Arabidopsis thaliana. Act. Physiol. Plant. 30, 723-727.

8. Attia, H., Arnaud, N., Karraya, N., Lachaâl, M. (2008) Long-term effects of mild salt stress on growth, ion accumulation and superoxide dismutase expression of Arabidopsis rosette leaves. Physiol. Plant. 132, 293-305.

9. Beadle, C. L. (1993) Growth analysis. 36-46. In: Hall, D. C., Scurlock, J. M. O., BolharNordenkampf, H. R., Leegod, R. C. Long, S. P. (eds) Photosynthesis and production in a changing environment, A field and laboratory manual, London.

10. Bhardwaj, N. V., Sharma, M. K. (2005) Genetic parameters and character association in tomato. Bangladesh. J. Agric. Res. 30, 49-56.

11. Bolarin, M. C., Perez-Alfocea, F., Cano, E. A., Estan, M. T., Caro, M. (1993) Growth, fruit yield, and ion concentration in tomato genotypes after pre-emergence and post-emergence salt treatments. $\mathrm{J}$. Am. Soc. Hortic. Sci. 118, 655-660.

12. Bradford, M. M. (1976) A rapid and sensitive method for the quantitation of microgram quantities of protein utilizing the principle of protein-dye binding. Anal. Biochem. 72, 248-254.

13. Chance, B., Maehly, S. K. (1955) Assay of catalase and peroxidases. Meth. Enzymol. 2, 764-775.

14. Cuartero, J., Boların, M. C., Asıns, M. J., Moreno, V. (2006) Increasing salt tolerance in the tomato. J. Exp. Bot. 5, 1045-1058.

15. Delf, E. M. (1912) Transpiration in succulent plants. Ann. Bot. 26, 409-440.

16. Demidchik, V., Maathuis, F. J. M. (2007) Physiological roles of non selective cation channels in plants: from salt stress to signaling and development. New Phytol. 175, 387-404.

17. Ding, M., Hou, P., Shen, X., Wang, M., Deng, S., Sun, J., Xiao, F., Wang, R., Zhou, X., Lu, C., Zhang, D., Zheng, X., Hu, Z., Chen, S. (2010) Salt-induced expression of genes related to $\mathrm{Na}^{+} / \mathrm{K}^{+}$and ROS homeostasis in leaves of salt-resistant and salt-sensitive poplar species. Plant. Mol. Biol. 73, 251-269.

18. Dionisio-Sese, M. L., Tolbita, S. (1999) Antioxidative responses of shoots and roots of wheat increasing $\mathrm{NaCl}$ concentration. J. Plant. Physiol. 155, 274-280.

19. Eryllmaz, F. (2006) The relationships between salt stress and anthocyanin content in higher plants Biotechnol. Biotechnol. Equip. 20, 47-52.

20. Eshed, Y., Zamir, D. (1995) The introgression-line (IL) population of S. pennellii in a processingtomato variety (M82) is an efficient tool for identification and mapping of QTL. Genetics 141 $1147-1162$

21. Eshed, Y., Zamir, D. (1994) A genomic library of Lycopersicon pennellii in L. esculentum: A tool for fine mapping of genes. Euphytica 79, 175-179.

22. Eshed, Y., Gera, G., Zamir, D. (1996) A genome-wide search for wild-species alleles that increase horticultural yield of processing tomatoes. 3, 877-886. 
23. Foolad, M. R. (2004) Recent advances in genetics of salt tolerance in tomato. Plant Cell. Tissue. Organ. Cult. 76, 101-119.

24. Foolad, M. R. (2007) Genome mapping and molecular breeding of tomato. Int. J. Plant Genomics 2007, 52. pp.

25. Frary, A., Keles, D., Pinar, H., Gol, D., Doganlar, S. (2011) NaCl tolerance in Lycopersicon pennellii introgression lines:QTL related to physiological responses. Biol. Plant 55, 461-468.

26. Frary, A., Göl, D., Keleş, D., Ökmen, B., Pınar, H., Şığva, Ö. H., Yemenicioğlu, A., Doğanlar, S (2010) Salt tolerance in Solanum pennellii: antioxidant response and related QTL. BMC Plant. Biol. 10, 58. pp.

27. Fridman, E., Liu, Y. S., Carmel-Goren, L., Gur, A., Shoresh, M., Pleban, T., Eshed, Y., Zamir, D. (2002) Two tightly linked QTLs modify tomato sugar content via different physiological pathways. Mol. Genet. Genomics 266, 821-826.

28. Gomez-Mestre, I., Alexander, P. R., Wiens, J. J. (2012) Phylogenetic analyses reveal unexpected patterns in the evolution of reproductive modes in frogs. Evolution 66, 1558-5646.

29. Haydar, A., Mandal, M. A., Ahmed, M. B., Hannan, M. M., Karim, R. (2007) Studies on genetic variability and interrelationship among different traits in tomato (Lycopesicon esculantum Mill.). Middle East J. Sci. Res. 2, 139-142.

30. Heath, R. L., Packer, L. (1968) Photoperoxidation in isolated chloroplasts. I. Kinetics and stoichiometry of fatty acid peroxidation. Arch. Biochem. Biophys. 125, 189-198.

31. Hoagland, D., Arnon, D. I. (1950) The water culture method for growing plants without soil. California. Agricultural Experiment Station.

32. Juan, M. M., Rivero, L. R., Juan, M. R. (2005) Evaluation of some nutritional and biochemical indicators in selecting salt-resistant tomato cultivars. Environ. Exp. Bot. 54, 193-201.

33. Kennedy, B. F., De Fillippis, L. F. (1999) Physiological and oxidative response to $\mathrm{NaCl}$ of the salt tolerant Grevillea ilicifolia and the salt sensitive Grevillea arenaria. J. Plant. Physiol. 155, 746-754.

34. Koji, Y., Shiro, M., Michio, K., Mitsutaka, T., Hiroshi, M. (2009) Antioxidant capacity and damages caused by salinity stress in apical and basal regions of rice leaf. Plant Prod. Sci. 12, 319-326.

35. Liang, Y. C. (1999) Effects of silicon on enzyme activity and sodium, potassium and calcium concentration in barley under salt stress. Plant. Soil. 209, 217-224.

36. Lichtenthaler, H. K. (1988) In Vivo Chlorophyll Fluorescence as a Tool for Stress Detection in Plants. Applications of Chlorophyll Fluorescene in Photosynthesis Research, Stress Physiology, Hydrobiology and Remote Sensing. 129-142.

37. Lieberman, M., Segev, O., Gilboa, N., Lalazar, A., Levin, I. (2004) The tomato homolog of the gene encoding UV damaged DNA binding protein 1 (DDB1) underlined as the gene that causes the high pigment-1 mutant phenotype. Theor. Appl. Genet. 108, 1574-1581.

38. Meloni, D. A., Oliva, M. A., Martinez, C. A., Cambraia, J. (2003) Photosynthesis and activity of superoxide dismutase, peroxidase and glutathione reductase in cotton under salt stress. Environ. Exp. Bot. 49, 69-76.

39. Mittova, V., Guy, M., Tal, M., Volokita, M. (2002) Response of the cultivated tomato and its wild salt-tolerant relative Lycopersicon pennellii to salt-dependent oxidative stress: increased activities of antioxidant enzymes in root plastids. Free Radic. Res. 36, 195-202.

40. Mittova, V., Tal, M., Volokita, M., Guy, M. (2002). Salt stress induces up-regulation of an efficient chloroplast antioxidant system in the salt-tolerant wild tomato species Lycopersicon pennellii but not in the cultivated species. Physiol. Plant. 115, 393-400.

41. Munns, R., Termaat, A. (1986) Whole-plant responses to salinity. Aust. J. Plant Physiol. 13, 143-160.

42. Munns, R., Tester, M. (2008) Mechanisms of Salinity Tolerance. Plant. Biol. 59, 651-681.

43. Murray, J. R., Hackett, W. P. (1998) Leaf anthocyanin content changes in Zea mays L. grown at low temperature: significance for the relationship between the quantum yield of PSII and the apparent quantum yield of $\mathrm{CO}_{2}$ assimilation. Photosyn. Res. 58, 213-219.

44. Nakano, Y., Asada, K. (1981) Hydrogen peroxide in scavenged by ascorbate-specific peroxidise in spinach chloroplast. Plant. Cell. Physiol. 22, 867-880. 
45. Oztekin, G. B., Tuzel, Y. (2011) Comparative Salinity Responses Among Tomato Genotypes and Rootstocks. Pak. J. Bot. 43, 2665-2672.

46. Ozturk, L., Demir, Y., Unlukara, A., Karatas, I., Kurunc, A., Duzdemir, O. (2012) Effects of long-term salt stress on antioxidant system, chlorophyll and proline contents in pea leaves Rom. Biotechnol. Lett. 17, 7227-7236.

47. Panda, S. K. (2001) Response of green gram seeds under salinity stress. Indian J. Plant. Physiol. 6, 438-440.

48. Parida, A. K., Das, A. B. (2005) Salt tolerance and salinity effects on plants: a review. Ecotoxicol. Environ. Saf. 60, 324-349.

49. Peralta, I. E., Spooner, D. M. (2005). Morphological characterization and relationships of wild tomatoes (Solanum L. Section Lycopersicon): A Festschrift for William G., D’Arcy. T. B., Croat V. C., Hollowell, R. C., Keating, M. Botanical Garden Press. 104, 227-257.

50. Perez-Alfocea, F., Estañ, M. T., Caro, M., Bolarin, M. C. (1993) Response of tomato cultivars to salinity. Plant. Soil. 150, 203-211.

51. Rajamane, N. N., Gaikwad, D. K. (2014) Effect of sodium chloride stress on polyphenol, flavonoid, anthocyanins contents and Lipid peroxidation of leaf lets of Simarouba glauca. Indian J. Pharm. Educ. Res. 1, 2350-1138

52. Rao, M. V. (1992) Cellular detoxifying mechanisms determine age dependent injury in tropical plants exposed to SO. J. Plant. Physiol. 140, 733-740.

53. Rodríguez-Rosales, M. P., Kerkeb, L., Bueno, P., Donaire, J. P. (1999) Changes induced by $\mathrm{NaCl}$ in lipid content and composition, lipoxygenase, plasma membrane $\mathrm{H}^{+}$-ATPase and antioxidant enzyme activities of tomato (Lycopersicon esculentum Mill.) calli. Plant. Sci. 143, 143-150.

54. Rus, A. M., Estañ, M. T., Gisbert, C., Garcia-Sogo, B., Serrano, R., Caro, M., Moreno, V., Bolarin, M. C. (2001) Expressing the yeast HAL1 gene in tomato increases fruit yield and enhances $\mathrm{K}^{+} / \mathrm{Na}^{+}$ selectivity under salt stress. Plant. Cell. Environ. 24, 875-880.

55. Saeed, M., Saleem, F., Zakria, M., Anjum, S. A., Shakeel, A., Saeed, N. (2011) Genetic variability of $\mathrm{NaCl}$ tolerance in tomato. Genet. Mol. Res. 10, 1371-1382.

56. Sairam, R. K., Rao, K. V., Srivastava, G. C. (2002) Differential response of wheat genotypes to long term salinity stress in relation to oxidative stress, antioxidant activity and osmolyte concentration. Plant. Sci. 163, 1037-1046.

57. Saranga, Y., Zamir, D., Marani, A., Rudich, J. (1991) Breeding tomatoes for salt tolerance - fieldevaluation of Lycopersicon germplasm for yield and dry-matter production. J. Am. Soc. Hort. Sci. 116, 1067-1071.

58. Savithri, H. S., Sudhakar, C. (1999) Total peroxidase activity and peroxidase isoforms as modified by salt stress in two cultivars of foxtail millet with differential salt resistance. Plant. Sci. 141, 1-9.

59. Shalata, A., Tal, M. (1998) The effect of salt stress on lipid peroxidation and antioxidants in the cultivated tomato and its wild salt-tolerant relative Lycopersicon pennellii. Physiol. Plant. 104, 169-174.

60. Sharifova, S., Mehdiyeva, S., Theodorikas, K., Roubos, K. (2013) Assessment of genetic diversity in cultivated tomato (Solanum lycopersicum L.) genotypes using raped primers. J. Hortic. Res. 21, 83-89.

61. Stevens, R., Buret, M., Duffé, P., Garchery, C., Baldet, P., Rothan, C., Causse, M. (2007) Candidate Genes and Quantitative Trait Loci Affecting Fruit Ascorbic Acid Content in Three Tomato Populations. Plant. Physiol. 143, 1943-1953.

62. Stevens, R., Buret, M., Garchery, C., Carretero, Y., Causse, M. (2007) Technique for rapid, smallscale analysis of vitamin $\mathrm{C}$ levels in fruit and application to a tomato mutant collection. J. Agric. Food Chem. 54, 6159-6165.

63. Stevens, R., Page, D., Gouble, B., Garchery, C., Zamir, D., Causse, M. (2008) Tomato fruit ascorbic acid content is linked with monodehydroascorbate reductase activity and tolerance to chilling stress. Plant. Cell. Environ. 31, 1086-1096. 
64. Taha, R., Mills, D., Heimer, Y., Tal, M. (2000) The relation between low $\mathrm{K}^{+} / \mathrm{Na}^{+}$ratio and salttolerance in the wild tomato species Lycopersicon pennellii. J. Plant Physiol. 157, 59-64.

65. Tal, M., Shannon, M. C. (1983) Salt tolerance in the wild relatives of the cultivated tomato: Responses of Lycopersicon esculentum. L. cheesmanii, L. peruvianum, solanum pennellii and $\mathrm{F}_{1}$ hybrids to high salinity. Aust. J. Plant Physiol. 10, 109-117.

66. Turhan, A., Seniz, V. (2010) Salt tolerance of some tomato genotypes grown in Turkey. J. Food. Agri. Environ. 8, 332-339.

67. Wang, W., Vinocur, B., Altman, A. (2003) Plant responses to drought, salinity and extreme temperatures: towards genetic engineering for stress tolerance. Planta 218, 1-14.

68. Witkoswski, E. T. F., Lamont, B. B. (1991) Leaf specific mass confounds leaf density and thickness. Oecologia 84, 362-370.

69. Xiong, L., Zhu, J. K. (2002) Salt tolerance. The Arabidopsis Book. American Society of Plant Biologists. Rockville.

70. Yagi, K. (1976) A simple fluorometric assay for lipoperoxide in blood plasma. Biochem. Med. 15, 212-216.

71. Yokas, I., Tuna, A. L., Bürün, B., Altunlu, H., Altan, F., Kaya, C. (2008) Response of the tomato (Lycopersicon esculentum Mill.) plant to exposure to different salt forms and rates. Turk. J. Agric. For. 32, 319-329. 